\title{
REKONSTRUKSI KONSEP JILBAB PERSPEKTIF MUHAMMAD SYAHRUR (Telaah terhadap Q.S. an-Nur [24]: 31 dan al-Ahzab [33]: 59)
}

\author{
Azkiya Khikmatiar \\ Fakultas Ushuluddin dan Pemikiran Islam \\ UIN Sunan Kalijaga Yogyakarta \\ Akhikmatiar@gmail.com
}

Diterima 13 Agustus 2019| Direview 22 Desember 2019| Diterbitkan 29 Desember 2019

\begin{abstract}
:
Syabrur is a contemporary Muslim scholar who offers an innovative theory in Islamic law that is the theory of limits (budud) which is divided into two namely the maximum limit (badd al-A'la) and the minimum limit (hadd alAdna). This paper will answer about how Mubammad Syahrur interprets the veil in Q.S. an-Nur [24]: 31 and alAhrab [33]: 59 by using his boundary theory. The results of the study of the two verses are on the minimum limit (hadd al-Adna) generally accepted is to cover the upper region (al-juyub al-ulwiyab), namely the area of the breast, under the armpit, and close the lower intimate area (al -juyub as-sufliyyah). While the maximum limit (hadd al-A'la) generally applicable is the part included in the category of al-juyüb, whether al-juyub al-'ulwiyyah or al-juyüb assufliyyah ie the whole body of women except the face and both palms.
\end{abstract}

Keywords: Mubammad Syahrur, hadd al-A'la, hadd al-Adna

\begin{abstract}
Abstrak:
Syabrur adalab cendekiawan Muslim kontemporer yang menawarkan teori inovatif dalam bukum Islam yaitu teori batas (budud). Teori ini dibagi ke dalam dua bentuk. yaitu batas maksimal (badd al-A'la) dan batas minimal (badd al-Adna). Tulisan ini akan menjawab persoalan bagaimana Mubammad Syahrur menafsirkan jilbab dalam Q.S. an-Nur [24]: 31 dan al-Ahzab [33]: 59 dengan melalui teori batasnya. Adapun basil penelitian terbadap dua ayat tersebut yaitu pada batas minimal (hadd al-Adna) yang berlaku secara umum adalab menutup daerah bagian atas (al-juyub al-ulwiyah), yaitu daerah payudara, bawah ketiak, dan menutup daerah intim bagian bawah (al-juyub assufliyyah). Sedangkan batas maksimal (badd al-A'la) yang berlaku secara umum adalab bagian yang termasuke dalam kategori al-juyūb, baik al-juyub al-ulwiyyah atan al-juyüb as-sufliyyah yaitu selurub tubuh perempuan kecuali wajah dan kedua telapak tangan.
\end{abstract}

Kata kunci : Muhammad Syahrur, hadd al-A'la, hadd al-Adna

\section{Pendahuluan}

Salah satu permasalahan perempuan yang seringkali menimbulkan pro dan kontra adalah pembahasan tentang penggunaan jilbab. Secara bahasa, jilbab adalah bentuk tunggal, bentuk jamaknya adalah jalabib. Jilbab berasal dari akar kata jäläbā, yang berarti membawa, mendatangkan. ${ }^{1}$ Sedangkan secara istilah jilbab diartikan sebagai kerudung lebar yang dipakai oleh perempuan muslimah untuk menutupi kepala dan leher sampai dengan dada. ${ }^{2}$

Menurut Quraish Shihab, jilbab diartikan sebagai baju kurung yang longgar dilengkapi kerudung penutup kepala. ${ }^{3}$ Adapun menurut Fatima Mernissi jilbab bukanlah jenis pakaian baru, melainkan cara baru untuk membedakan perempuan merdeka dan hamba sahaya. Menurutnya, jilbab adalah konsep yang samar, karena kata tersebut bisa berarti gamis maupun jubah. Selain itu, jilbab dapat didefinisikan sebagai pakaian lebar yang digunakan oleh perempuan, sedangkan dalam definisi lain, jilbab sebagai pakaian yang digunakan wanita untuk menutup kepala dan dada mereka. ${ }^{4}$

${ }^{1}$ Ahmad Warson Munawwir, al-MunawnIr Kamus Arab Indonesia, (Surabaya: Pustaka Progressif, 1997), 19.

${ }^{2}$ W.J.S. Poerwadarminta, Kamus Umum Bahasa Indonesia Edisi Ketiga, (Jakarta: Balai Pustaka, 2007), 490. 2000), 172 .

${ }^{3}$ Quraish Shihab, Wawasan al-Qur'an, Tafsir Maudhu'i atas Pelbagai Persoalan Umat, (Bandung: Mizan,

${ }^{4}$ Fatima Mernissi, Wanita di dalam Islam, terj. Yaziar Radianti, (Bandung: Pustaka, 1994), 229-230.

DOI: $10.18592 /$ jiiu.vovi\%i.3204 
Ketika berbicara tentang jilbab maka setidaknya terdapat dua hal yang berkaitan dengannya yaitu pakaian dan aurat. Jika melihat dalam konteks sejarah tentang jilbab, perempuan Arab jauh sebelum Islam telah menggunakan jilbab. Bahkan jilbab juga digunakan oleh bangsa selain Arab. ${ }^{5}$ Akan tetapi, dalam pandangan masyarakat secara umum, jilbab merupakan pakaian yang digunakan seorang perempuan muslimah untuk menutup aurat sekaligus sebagai bentuk identitas keislamannya. Jadi, dapat dikatakan bahwasanya ketika aurat seorang perempuan muslimah sudah tertutup maka pakaian seperti apapun diperbolehkan, tidak terkecuali jilbab.

Selanjutnya, para ulama kontemporer berbeda pendapat tentang permasalahan menutup aurat bagi perempuan muslimah. Mayoritas ulama tafsir, berpendapat bahwasanya aurat perempuan itu seluruh tubuh kecuali wajah dan telapak tangan. ${ }^{6}$ Diantara yang berpendapat wajib adalah Maududi. ${ }^{7}$ Sedangkan yang berpendapat hanya anjuran adalah Mutawalli Al-Sa'rawi. ${ }^{8}$ Adapun yang berpendapat tidak wajib adalah Quraish Shihab, Muhammad Sa'id Al-Asmawi, ${ }^{10}$ dan Qasim Amin. ${ }^{11}$

Muhammad Syahrur adalah pemikir muslim kontemporer yang menawarkan metodologi baru dalam menafsirkan al-Qur'an yaitu dengan teori batas. menurutnya hukum tidak boleh bersifat tunggal dengan satu pemahaman dan perspektif. Hukum Tuhan harus sesuai dengan kecendrungan manusia yang selalu berubah, maju, dan berkembang. Maka dalam al-Qur'an akan selalu dijumpai bahwa syar'i hanya menentukan batasan-batasan (budud) saja, ada yang berupa batasan maksimal (al-hadd al- $A^{\prime}$ la) atau batasan minimal (al-badd al-Adna) maupun variasi dari keduanya.

Di dalam al-Qur'an setidaknya terdapat dua ayat yang menjadi legitimasi tentang jilbab atau pakaian untuk menutup aurat yaitu pada Q.S. An-Nur[24]: 31 ${ }^{12}$ dan Q.S. Al-Ahzab[33]:

${ }^{5}$ Fadwa El Guindi, Jilbab: Antara Kesalehan, Kesopanan dan Perlawanan, terj. Mujiburohman (Jakarta: Serambi, 2003), 39.

${ }^{6}$ Qabila Salsabila, Reza Pahlevi dan Ali Masrur, Penafsiran Ayat-Ayat Tentang Aurat Perempuan Menurut Mubammad Syahrur, Al-Bayan: Jurnal Studi al-Qur'an dan Tafsir 2, 1 Juni 2017), 179.

${ }^{7}$ Menurutnya, perintah-perintah dalam al-Quran meskipun ditunjukkan kepada istri-istri Nabi saw, akan tetapi tetapi juga mengikat semua perempuan muslimah.

${ }^{8}$ Menurutnya, busana yang sesuai dengan syariat Islam adalah busana yang dapat menutupi seluruh tubuhnya, selain wajah dan telapak tangan. Serta diisyaratkan juga agar perempuan tersebut menggunakan pakaian yang tidak sempit, karena pakaian yang sempit dapat membentuk tubuh perempuan, jangan sampai menggunakan pakaian tipis dan menerawang sehingga bagian tubuh perempuan yang berada didalam busana tersebut terlihat. Bahkan seandainya, jika dia merasa khawatir terjadinya fitnah, maka ia diwajibkan memakai penutup wajah dan telapak tangan busana yang sesuai dengan syariat Islam adalah busana yang dapat menutupi

${ }^{9}$ Menurutnya, perempuan tidak wajib mengenakan jilbab karena jilbab merupakan adat budaya Arab, yang dilakukan karena tradisi bukan karena kewajiban. Penggunaan jilbab disesuaikan dengan situasi dan kondisi kebutuhan. Wanita yang menutup seluruh badannya atau kecuali wajah dan telapak tangannya telah menjalankan teks ayat-ayat Alquran bahkan mungkin berlebih. Namun dalam saat yang sama kita tidak wajar menyatakan terhadap mereka yang tidak memakai kerudung, atau menampakkan setengah tangannya, bahwa mereka secara pasti telah melanggar petunjuk agama.

${ }^{10}$ Menurutnya, jilbab itu tidak wajib. Menurutnya jilbab adalah produk budaya Arab. Bahkan ia mengatakan bahwa ayat tentang hijab itu tidak mengandung ketetapaan hukum qat" $i$ dan hadis-hadis yang menjadi rujukan tentang kewajiban jilbab atau hijab itu adalah hadis Ahad yang tidak bisa dijadikan landasan hukum tetap. Bila jilbab itu wajib di pakai perempuan, maka dampaknya akan besar.

${ }^{11}$ Menurutnya hijab harus ditegaskan karena ia merupakan bentuk ajaran agama Islam dan memiliki nilai positif bagi pergaulan laki-laki dan perempuan. Namun lima tahun kemudian, pembelaannya tersebut dia bantah sendiri dalam bukunya "Tahrir Al-Mar'ab" menurutnya, hijab hanya tradisi orang Arab dan bukan kewajiban dalam agama Islam. Maka perubahan tradisi berhijab sangat memungkinkan sesuai dengan tuntunan zaman sebagaimana tradisi hijab dalam bangsa Yunani atau Europa.

${ }^{12}$ Adapun ayat yang dimaksudkan adalah sebagai berikut :

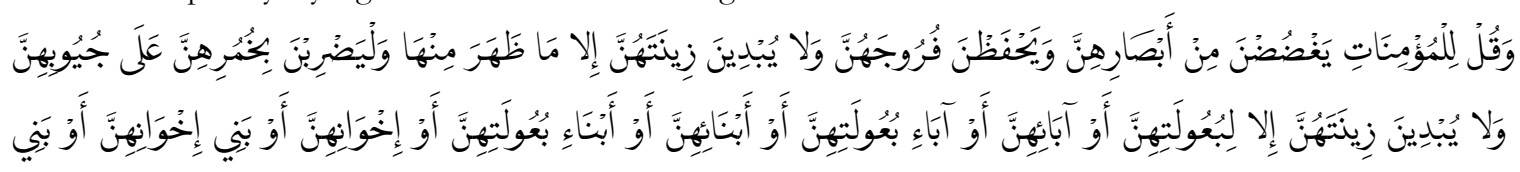


59. ${ }^{13}$ Syahrur menafsirkan ayat tersebut dengan menggunakan teori hududnya. Menurut Syahrur, ayat tersebut menjelaskan tentang batas minimal dan juga batas maksimal bagi perempuan untuk menutup auratnya.

Oleh karenanya, dalam tulisan sederhana ini penulis memilih konsep jilbab dalam alQur'an sebagai objek material penelitian. Sedangkan objek formalnya adalah teori hudud Muhammad Syahrur dalam memahami konsep jilbab dalam al-Qur'an. Secara umum, tulisan ini akan menjawab tentang bagaimana Syahrur memahami konsep jilbab dalam al-Qur'an dengan teori hududnya. Selain itu, tulisan ini juga akan memberikan kritik terhadap pemahaman Syahrur terhadap konsep jilbab dalam al-Qur'an.

\section{Biografi Muhammad Syahrur}

Nama lengkapnya Muhammad Ibnu Da'ib Syahrur (selanjutnya disebut Syahrur). Beliau seorang pemikir muslim kontemporer yang lahir pada tanggal 11 Maret tahun 1938 di Damakus (Syiria). ${ }^{14}$ Beliau adalah putra dari pasangan Da'ib bin Da'ib dan Siddiqah binti Salih Filyun. Selanjutnya, Syahrur menikah dengan Azizah ${ }^{15}$ dan dikaruniai lima orang anak, yaitu Tariq, Al-Lais, Basul, Masum, dan Rima. ${ }^{16}$

Pada awalnya, Syahrur tidak pernah belajar ilmu-ilmu keislaman secara intensif. Setelah menamatkan pendidikan tingkat dasar dan menengah di lembaga pendidikan 'Abd alRahman al-Kawakibi di tanah kelahirannya. ${ }^{17}$ Kemudian beliau pergi ke Uni Soviet untuk mengambil program diploma di bidang teknik sipil di Moskow. Setelah di Moskow, Syahrur kembali Syiria pada tahun 1964 dan bekerja sebagai dosen di Universitas Damaskus. ${ }^{18}$

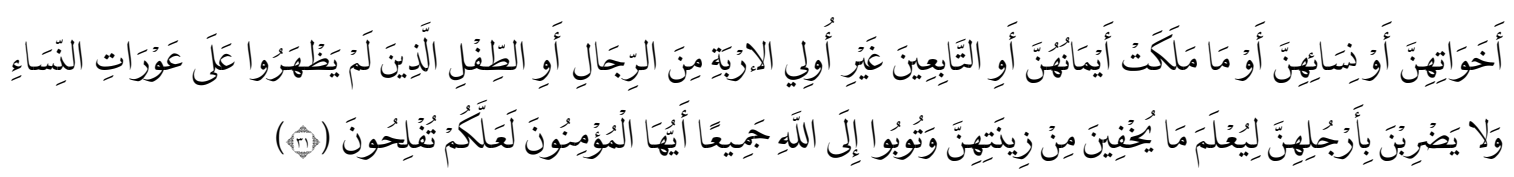

"Katakanlah kepada wanita yang beriman: "Hendaklah mereka menahan pandangannya, dan kemaluannya, dan janganlah mereka Menampakkan perbiasannya, kecuali yang (biasa) nampak dari padanya. dan hendaklah mereka menutupkan kain kudung kedadanya, dan janganlab Menampakekan perbiasannya kecuali kepada suami mereka, atau ayah mereka, atan ayah suami mereka, atau putera-putera mereka, atau putera-putera suami mereka, atan saudara-saudara lakilaki mereka, atau putera-putera saudara lelaki mereka, atau putera-putera saudara perempuan mereka, atau wanita-wanita Islam, atau budak-budak yang mereka miliki, atau pelayan-pelayan laki-laki yang tidak mempunyai keinginan (terhadap wanita) atau anak-anak, yang belum mengerti tentang aurat wanita. dan janganlah mereka memukulkan kakinyua agar diketabui perbiasan yang mereka sembunyikan. dan bertaubatlab kamu sekalian kepada Allah, Hai orang-orang yang beriman supaya kamu beruntung."

${ }^{13}$ Adapun ayat yang dimaksudkan adalah sebagai berikut :

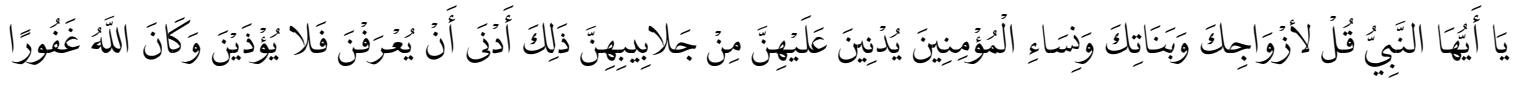

"Hai Nabi, Katakanlah kepada isteri-isterimu, anak-anak perempuanmu dan isteri-isteri orang mukmin: "Hendaklah mereka mengulurkan jilbabnya ke selurub tubub mereka". yang demikian itu supaya mereka lebih mudah untuk dikenal, karena itu mereka tidak di ganggu. dan Allab adalah Maha Pengampun lagi Maba Penyayang."

${ }^{14}$ Kota ini telah dibangun sejak 3000 tahun sebelum Masehi, bahkan menurut legenda dinyatakan Nabi Hud as. adalah orang pertama yang membangun kota ini setelah terjadi banjir besar melanda dunia. Kota ini secara bergantian dikuasai oleh kerajaan Assyiria, Yunani, Romawi dan Bizantiyum. Islam masuk ke Damaskus pada bulan September 653 M. Ketika itu Syiria dikuasai bangsa Romawi kemudian ditaklukkan oleh tentara Islam di bawah pimpinan panglima perang Islam ternama seperti Khalid bin Walid ra dan Amr bin 'Ash pada masa khalifah Umar bin Khaththab ra. Lihat Tim Penulis Ensiklopedi Islam, Ensiklopedi Islam, Jilid I, (Jakarta: PT. Ichtiar Baru Van Hoeve, 2003), 283.

${ }^{15}$ Ahmad Zaki Mubarok, Pendekatan Strukturalisme Linguistik dalam Tafsir al-Qur'an Kontemporer "ala" M. Syahrur, (Yogyakarta: eLSAQ Press, 2007), 137. 2003), 43.

${ }^{16}$ Ahmad Syarqawi Ismail, Rekonstruksi Konsep Wabyu Mubammad Syahrur, (Yogyakarta: eLSAQ Press,

${ }^{17}$ Muhammad Syahrur, Epistimologi Qur'ani: Tafsir Kontemporer Ayat-ayat al-Qur'an Berbasis MaterialismeDialektika-Historis, terj. M. Firdaus, (Bandung: Penerbit Marja, 2015), 5.

${ }^{18}$ Muhammad Syahrur, Islam dan Iman: Aturan-aturan Pokok, terj. M. Zaid Su'di, (Yogyakarta: Penerbit Jendela, 2002), xiii. 
Kemudian pada tahun 1967, beliau memperoleh kesempatan untuk melakukan penelitian Imperial College di London Inggris, akan tetapi beliau terpaksa harus kembali ke Syiria karena pada waktu itu, tepatnya Juni tahun 1967 terjadi perang Syiria dan Israil yang mengakibatkan hubungan diplomatik antara Syiria dengan Inggris menjadi terputus. ${ }^{19}$

Selanjutnya, pada tahun 1968, Syahrur memutuskan pergi Dublin Irelandia sebagai utusan dari Universitas Damaskus dalam rangka mengambil program Master dan Doktor di National University. Bidang keilmuan yang diambil adalah Mekanika Pertahanan dan Teknik Pembangunan. Berkat ketekunannya, pada tahun 1969 beliau berhasil meraih gelar Master of Science, sedangkan gelar Doktornya diraih pada tahun 1972. ${ }^{20}$ Beliau diangkat sebagai Profesor jurusan Teknik Sipil di Universitas Damaskus pada tahun 1972 sampai 1999. ${ }^{21}$

Setelah menyelesaikan studinya di Ireland National University, Syahrur kembali ke Syiria dan resmi menjadi dosen di Universitas Damaskus dan mengampu mata kuliah Mekanika Pertahanan dan Geologi. Selain menjadi dosen, beliau juga menjadi konsultan di bidang teknik. Pada tahun 1982-1983, Syahrur dikirim lagi oleh pihak Univeristas untuk menjadi staf ahli di al-Saud Consult, Saudi Arabia. Bersama rekannya, beliau membuka biro konsultan Teknik di Damaskus.

Kemudian, pada 1995, Syahrur diundang untuk menjadi peserta kehormatan dan ikut terlibat dalam debat publik mengenai mengenai pemikiran Islam di Libanon dan Maroko. Pada awalnya beliau memang lebih menekuni bidang teknik, namun pada pekembangannya, beliau mulai tertarik pada kajian-kajian keislaman, terutama sejak beliau berada di Dublin Ireland. Sejak saat itulah beliau mulai mengkaji al-Qur'an secara lebih serius dengan pendekatan ilmu filsafat bahasa dan dibingkai dengan teori ilmu eksak, bahkan beliau juga menulis buku dan artikel tentang pemikiran keislaman untuk merespon isu-isu kontemporer. ${ }^{22}$

Dalam hal ini Ja'far Dakk al-Bab, yang merupakan teman sekaligus gurunya, memiliki peran yang sangat besar dalam mendukung karir intelektual-akademik Syahrur. Pertemuan Syahrur dan Ja'far Dakk al-Bab terjadi ketika keduanya sama-sama menjadi mahasiswa di Uni Soviet. Pada waktu itu, Ja'far Dakk al-Bab mengambil jurusan Linguistik, sedangkan Syahrur mengambil Jurusan Teknik Sipil. Persahabatan itu terjadi sekitar tahun 1958 hingga tahun 1964, meski setelah itu keduanya berpisah karena sama-sama telah selesai dalam studinya. Akan tetapi secara tidak sengaja, keduanya bertemu lagi pada tahun 1980, di Ireland, Dublin. Pada saat itulah terjadi perbincangan intensif di antara keduanya mengenai masalah bahasa, filsafat dan al-Qur'an. Syahrur pun tertarik lebih jauh untuk mengkaji bahasa, filsafat, dan al-Qur'an. Sejak saat itu Syahrur belajar Linguistik secara intensif dari disertasi Ja 'far Dakk al-Bab yang dipromosikan pada tahun 1973 di Moskow. ${ }^{23}$

Berkat kesungguhannya dalam mengkaji al-Qur'an, filsafat, dan bahasa, Syahrur berhasil menulis karya ilmiah yang bukan saja monumental, tetapi juga kontroversial dengan judul Al-Kitab wa al-Qur'an; Qira'at Al-Mu'asyirah pada tahun 1990. Buku tersebut merupakan hasil evolusi dan pengendapan pikiran beliau yang cukup lama, yakni kurang lebih 20 tahun. ${ }^{24}$

Selanjutnya, menurut Eikelman Piscatori sebagaimana dikutip Bisri Effendi berpendapat bahwasanya buku-buku Syahrur secara umum mencoba melancarkan kritik terhadap sebuah kebijakan agama konvensional maupun kepastian radikal keagamaan yang tidak toleran. Dari hal tersebut maka dapat dikatakan bahwa apa yang diinginkan oleh

\footnotetext{
${ }^{19}$ Abdul Mustaqim, Epstemologi Tafsir Kontemporer, (Yogyakarta: LkiS, 2008), 94.

${ }^{20}$ M. Aunul Abied, Islam Garda Depan; Mozaik Pemikiran Islam Timur Tengah, (Bandung: Mizan 2001), 237.

${ }^{21}$ Muhammad Syahrur, Prinsip dan dasar Hermeneutika al-Qur'an Kontemporer, terj. Sahiron Syamsuddin, (Yogyakarta: eLSAQ Prees, 2008), Biografi penulis.

${ }^{22}$ Abdul Mustaqim, Epstemologi Tafsir Kontemporer, 94.

${ }^{23}$ Abdul Mustaqim, Epstemologi Tafsir Kontemporer, 95.

${ }^{24}$ Abdul Mustaqim, Epstemologi Tafsir Kontemporer, 96.
} 
Syahrur sebenarnya adalah perlunya menafsirkan ulang ayat-ayat al-Qur'an sesuai dengan perkembangan dan interaksi antar generasi, serta mendobrak kejumudan penafsiran alQur'an. Dalam kajian hermeneutika, Syahrur menunjukkan kreatifitas penafsirannya dengan cara memperkenalkan istilah tsabat al-nash wa taghayyur al-mubtawa, yang berarti bahwa alQur'an teksnya tetap akan tetapi kandungan makna teks tersebut mengalami perubahan, sehingga dapat ditafsirkan secara dinamis sesuai dengan perkembangan zaman. ${ }^{25}$

Syahrur dapat disebut sebagai pemikir kontemporer yang produktif. Karya-karyanya disamping buku-buku yang terkait dengan Teknik Bangunan, antara lain: (1) Qur'an: Qira'ah Mu'ashirah (1992); (2) Dirasah Islamiyyah Mu'asirah fi al-Dawlah wa al-Mujtama' (1994), (3) alIslam wa al-Iman;Manzumat al-Qiyam (1996), (4) Masyru' Misaq al-'Amal al-Islami. (1999), (5) Nabwa Usul Jadidah li al-Fiqhi al-Islami (2000), (6) al-Sunnah al-Rasuliyyah wa al-sunnah alNabawiyyah, (2012). ${ }^{26}$

Selain menulis buku, beliau juga menulis beberapa artikel yang dimuat di berbagai jurnal, diantaranya "The Divine Text and Pluralism in Muslim Societies", dalam Muslim Politics Report, 14 (1997), dan "Islam and the 1995 Beijing World Conference on Woman", dalam Kuwaiti Newspaper, dan dipublikasikan juga dalam Charles Kurzman (ed.), Liberal Islam: A Sourcebook (New York \& Oxford: Oxford University Press, 1998). ${ }^{27}$

Disamping produktif dalam berkarya, Syahrur juga dikritik dengan beberapa tulisan, misalnya Mujarrad al-Tanjim al-Qur'an Li Duktur Mubammad Syahrur karya Muslim al-jabi, Tabafut al-Qira'an al-Mu'ashirah karya al-Syawwaf, sedangkan tulisan yang mengapresiasi adalah tulisan dengan judul The Syahrur Phenomenon: a Liberal islamic Voice From Syiria karya Peter Clark. Kritikan terhadap beliau bahkan tidak jarang membawanya diklaim sebagai agen zionis, Marxian, inkar sunnah dan lain-lain. ${ }^{28}$

Dari uraian di atas jelaslah bahwasanya Syahrur tidak pernah tercatat bergabung dengan Institusi Islam manapun atau pernah mengikuti pelatihan resmi dan memperoleh sertifikat dalam bidang ilmu-ilmu keislaman. Pengetahuan keislaman beliau diperolehnya secara otodidak. Hal tersebut sekaligus membuktikan komprehensifnya pengetahuan beliau tidak hanya tentang teknik, melainkan juga tentang kesilaman.

\section{Teori Hudud (Teori Batas)}

Syahrur dikenal sebagai cendekiawan Muslim yang menawarkan berbagai teori inovatif dalam hukum Islam. Salah satu teori yang ditawarkannya adalah tentang teori hudud (teori batas). Teori hudud dapat digambarkan sebagai perintah Allah yang diungkapkan dalam alQur'an dan Sunnah. Perintah tersebut mengandung ketentuan-ketentuan yang merupakan batas terendah (al-had al-adna) dan batas tertinggi (al-had al-a'la) untuk seluruh perbuatan manusia. $^{29}$

Teori batas menurut Abdul Mustaqim dalam bukunya yang berjudul "Epistemologi Tafsir Kontemporer" mempunyai dua kontribusi. Pertama, dengan teori batas, ayat-ayat hukum yang selama ini dianggap final dan pasti tanpa ada alternatif pemahaman lain ternyata memiliki kemungkinan untuk diinterpretasikan secara baru dan Syahrur mampu menjelaskannya secara metodologis dan mengaplikasikannya dalam penafsirannya melalui pendekatan matematis. Kedua, dengan teori batas, seorang mufassir akan mampu menjaga sakralitas teks tanpa harus kehilangan kreatifitasnya dalam melakukan ijtihad untuk

${ }^{25}$ Abdul Mustaqim, dkk, Kajian al-Qur'an dan Hadis dalam Dialektika Kontemporer, (Yogyakarta: Idea Press, 2014), 92.

${ }^{26}$ Muhammad Syahrur, Prinsip dan dasar Hermeneutika al-Qur'an Kontemporer, hlm. Biografi penulis. Lihat juga Muhammad Syahrur, Metodologi Fiqih islam Kontemporer, terj. Sahiron Syamsuddin, (Yogyakarta: Kalimera, 2015), 547.

${ }^{27}$ Abdul Mustaqim, Epstemologi Tafsir Kontemporer, 107.

${ }^{28}$ Kurdi, dkk, Hermenentika al-Qur'an dan Hadis, (Yogyakarta: eLSAQ Press, 2010), 288.

${ }^{29}$ Muhammad Syahrur, Prinsip dan dasar Hermeneutika al-Qur'an Kontemporer, 6-7. 
membuka kemungkinan interpretasi sepanjang masih berada dalam batas-batas hukum Allah. ${ }^{30}$

Selanjutnya, berdasarkan kajiannya terhadap ayat-ayat hukum, Syahrur menyimpulkan bahwasanya ada enam bentuk dalam teori batas yang dapat digambarkan dalam bentuk matematis. ${ }^{31}$ Adapun perinciannya adalah sebagai berikut:

Pertama, Halah al-had al-a'la (posisi batas maksimal). Daerah hasil (range) dari persamaan fungsi $\mathrm{Y}=\mathrm{F}(\mathrm{x})$ berbentuk kurva tertutup yang hanya memiliki satu titik batas maksimum. Titik tersebut terletak berhimpit dengan garis lurus yang sejajar dengan sumbu X. Halah al had al-a'la hanya memiliki batas maksimal saja, sehingga dalam hal penetapan hukum tidak boleh melebihi batas maksimal. Akan tetapi, boleh dibawahnya atau tetap pada garis atau batas maksimal yang ditentukan oleh Allah Swt. ${ }^{32}$

Misalnya, ayat-ayat yang menjelaskan tentang hukuman potong tangan bagi pencuri laki-laki dan perempuan dalam Q.S. Al-Maidah[5]: 38. ${ }^{33}$ Menurut Syahrur, hukuman potong tangan baik bagi laki-laki maupun perempuan merupakan batas hukuman maksimal. Oleh karenanya seorang hakim tidak boleh menetapkan hukuman kepada pencuri melebihi batas maksimal tersebut. Akan tetapi, ia boleh menetapkan hukuman yang lebih rendah dari hukuman potong tangan sesuai dengan situasi dan kondisi yang objektif.

Kedua, Halah al-hadd al-adna (posisi batas minimal). Daerah hasilnya berbentuk kurva tebuka yang memiliki satu titik batas minimum. Titik ini terletak berhimpit dengan garis lurus yang sejajar dengan sumbu X. Dalam posisi tersebut, suatu keputusan hukum boleh dilakukan di atas batas minimal yang telah ditentukan dalam al-Qur'an atau berada pada batas minimal yang ditetapkan, akan tetapi tidak boleh melebihi batas minimal tersebut. ${ }^{34}$

Misalnya, ayat-ayat yang menjelaskan tentang maharim atau perempuan-perempuan yang tidak boleh dinikahi dalam Q.S. An-Nisa[4]: 22-23. ${ }^{35}$ Menurut Syahrur, ayat tersebut

${ }^{30}$ Abdul Mustaqim, Epistemologi Tafsir Kontemporer, 93.

${ }^{31}$ Sahiron Syamsuddin, dkk. Hermeneutika al-Qur'an; Madz̧hab Yogya, (Yogyakarta: Penerbit Islamika, 2003), 159.

${ }^{32}$ Abdul Mustaqim, dkk, Kajian al-Qur'an dan Hadis dalam Dialektika Kontemporer, 103.

${ }^{33}$ Adapun ayat yang dimaksudkan adalah sebagai berikut :

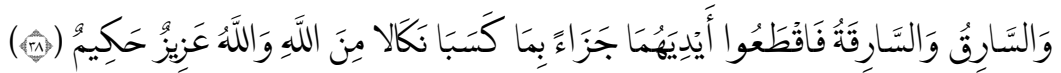

"Laki-laki yang mencuri dan perempuan yang mencuri, potonglah tangan keduanya (sebagai) pembalasan bagi apa yang mereka kerjakan dan sebagai siksaan dari Allah. dan Allah Maha Perkasa lagi Maha Bijaksana".

${ }^{34}$ Abdul Mustaqim, dkk, Kajian al-Qur'an dan Hadis dalam Dialektika Kontemporer, 105. ${ }^{35}$ Adapun ayat yang dimaksudkan adalah sebagai berikut :

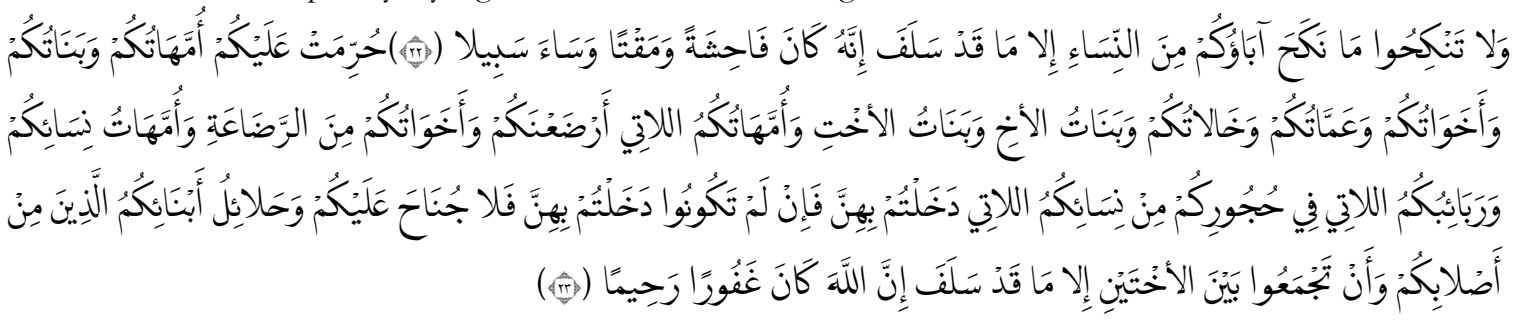

"Dan janganlah kamu kawini wanita-wanita yang telah dikawini oleh ayahmu, terkecuali pada masa yang telah lampau. Sesungguhnya perbuatan itu Amat keji dan dibenci Allah dan seburuk-buruk jalan (yang ditempuh). Diharamkan atas kamu (mengawini) ibu-ibumu; anak-anakmu yang perempuan, saudara-saudaramu yang perempuan, saudara-saudara bapakmu yang perempuan; saudara-saudara ibumu yang perempuan; anakanak perempuan dari saudara-saudaramu yang laki-laki; anak-anak perempuan dari saudara-saudaramu yang perempuan; ibu-ibumu yang menyusui kamu; saudara perempuan sepersusuan; ibu-ibu isterimu (mertua); anakanak isterimu yang dalam pemeliharaanmu dari isteri yang telah kamu campuri, tetapi jika kamu belum campur dengan isterimu itu (dan sudah kamu ceraikan), Maka tidak berdosa kamu mengawininya; (dan diharamkan bagimu) isteri-isteri anak kandungmu (menantu); dan menghimpunkan (dalam perkawinan) dua perempuan yang bersaudara, kecuali yang telah terjadi pada masa lampau; Sesungguhnya Allah Maha Pengampun lagi Maha Penyayang". 
merupakan batas minimal dalam hal perempuan-perempuan yang boleh dinikahi. Oleh karenanya, dalam kondisi apapun seseorang tidak diperbolehkan menikahi mereka yang dilarang dalam ayat tersebut, meskipun didasarkan dengan ijtihad.

Ketiga, Halah al-haddayn al-a'la wa al-adna ma'an (posisi batas maksimal bersamaan dengan batas minimal). Daerah hasilnya berupa kurva tertutup dan terbuka yang masingmasing mamiliki titik balik maksimum dan minimum. Kedua titik balik tersebut terletak berhimpit dengan garis lurus yang sejajar dengan sumbu X. Dalam posisi tersebut, penetapan hukum dilakukan di antara kedua batas tersebut. Pada sebagian ayat-ayat hudud ada yang mempunyai batas maksimal dan juga batas minimal sekaligus, sehingga penetapan hukumnya dapat dilakukan diantara kedua batas tersebut. ${ }^{36}$

Misalnya, ayat-ayat yang menjelaskan tentang pemabagian harta warisan dalam Q.S. An-Nisa[4]: 11-14. ${ }^{37}$ Menurut Syahrur, pembagian harta warisan mempunyai dua batas sekaligus, yaitu batas maksimal dan batas minimal. Oleh karenanya, hal tersebut harus diterapkan sesuai dengan batas-batas yang ditentukan dalam ayat tersebut.

Keempat, Halah al-mustaqim (posisi lurus). Daerah hasilnya berupa garis lurus sejajar dengan sumbu X. Karena berbentuk garis lurus, posisi ini meletakkan titik balik maksimum berimpit dengan titik balik minimum. Dalam posisi tersebut, ayat hudud tidak mempunyai batas minimal maupun maksimal, sehingga tidak ada alternatif hasil dari penerapan hukumannya selain yang disebutkan dalam ayat tersebut. Dengan kata lain, hukum tidak berubah meskipun zaman telah berubah. ${ }^{38}$

Misalnya, ayat-ayat yang menjelaskan tentang hukuman bagi pelaku zina dalam Q.S. An-Nur[24]: 2. ${ }^{39}$ Menurut Syahrur, tidak ada pilihan lain bagi pelaku zina baik laki-laki maupun perempuan selain dicambuk sebanyak seratus kali. Oleh karenanya, dalam menerapkan hukuman zina, seseorang tidak boleh menaruh rasa kasihan kepada pelaku zina tersebut.

${ }^{36}$ Abdul Mustaqim, dkk, Kajian al-Qur'an dan Hadis dalam Dialektika Kontemporer, 108.

${ }^{37}$ Adapun ayat yang dimaksudkan adalah sebagai berikut :

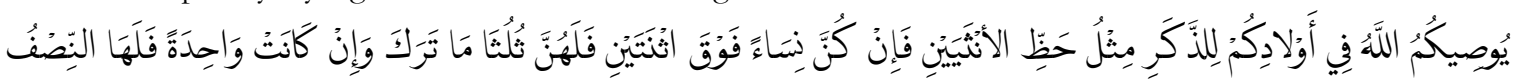

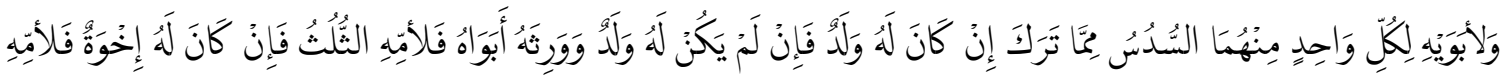

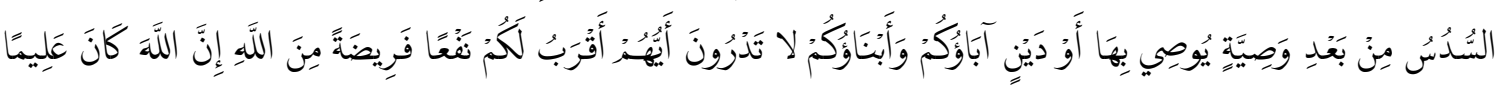

“Allah mensyari'atkan bagimu tentang (pembagian pusaka untuk) anak-anakmu. Yaitu : bahagian seorang anak lelaki sama dengan bagahian dua orang anak perempuan; dan jika anak itu semuanya perempuan lebih dari dua, Maka bagi mereka dua pertiga dari harta yang ditinggalkan; jika anak perempuan itu seorang saja, Maka ia memperoleh separo harta. dan untuk dua orang ibu-bapa, bagi masing-masingnya seperenam dari harta yang ditinggalkan, jika yang meninggal itu mempunyai anak; jika orang yang meninggal tidak mempunyai anak dan ia diwarisi oleh ibu-bapanya (saja), Maka ibunya mendapat sepertiga; jika yang meninggal itu mempunyai beberapa saudara, Maka ibunya mendapat seperenam. (Pembagian-pembagian tersebut di atas) sesudah dipenuhi wasiat yang ia buat atau (dan) sesudah dibayar hutangnya. (Tentang) orang tuamu dan anakanakmu, kamu tidak mengetahui siapa di antara mereka yang lebih dekat (banyak) manfaatnya bagimu. ini adalah ketetapan dari Allah. Sesungguhnya Allah Maha mengetahui lagi Maha Bijaksana".

${ }^{38}$ Abdul Mustaqim, dkk, Kajian al-Qur'an dan Hadis dalam Dialektika Kontemporer, 109.

${ }^{39}$ Adapun ayat yang dimaksudkan adalah sebagai berikut :

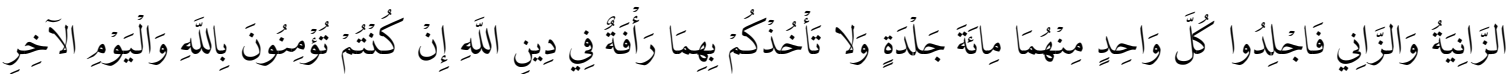

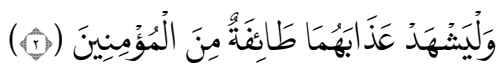

"Perempuan yang berzina dan laki-laki yang berzina, Maka deralah tiap-tiap seorang dari keduanya seratus dali dera, dan janganlah belas kasihan kepada keduanya mencegah kamu untuk (menjalankan) agama Allah, jika kamu beriman kepada Allah, dan hari akhirat, dan hendaklah (pelaksanaan) hukuman mereka disaksikan oleh sekumpulan orang-orang yang beriman". 
Kelima, Halah al-hadd al-a'la duna al-mamas bi al-hadd al-adna abadan (posisi batas maksimal mendekat tanpa menyentuh batas minimal). Daerah hasilnya berupa kurva terbuka yang terbentuk dari titik pangkal yang hampir berhimpit dengan sumbu $\mathrm{X}$ dan titik final yang hampir berhimpit dengan sumbu Y. Secara matematis, titik final hanya benar-benar berhimpit dengan sumbu Y pada daerah tak terhingga ('ala la nibayah). Dalam posisi tersebut, posisi batas minimal cenderung mendekat tanpa ada persentuhan sama sekali, kecuali pada daerah yang tidak terhingga. ${ }^{40}$

Misalnya, dalam batasan hubungan antara laki-laki dan perempuan. Hubungan tersebut berawal dari batasan minimal, berupa hubungan biasa tanpa persentuhan sama sekali. Kemudian berakhir pada batasan maksimal, berupa hubungan yang mendekati garis mustaqim yaitu batas perzinaan. Garis mustaqim tidak mempunyai batas minimal dan maksimal karena hanya ditandai dengan satu garis lurus. Garis lurus tersebut ditetapkan oleh Allah sebagai hubungan antara laki-laki dan perempuan di luar nikah atau yang biasa disebut zina. Oleh karenanya, al-Qur'an menggunakan redaksi wala taqrabu al-zina dan wala taqrabu alfawahisys. Hal tersebut memberikan pengertian bahwasanya pendekatan tersebut jika diteruskan maka akan menjerumuskan kedalam larangan Allah Swt.

Keenam, Halah al-hadd al-a'la mujaban wa al-hadd al-adna saliban (posisi batas maksimal positif dan batas minimal negatif). Daerah hasilnya berupa kurva gelombang dengan titik balik maksimum yang berada di daerah positif (kedua variabel $\mathrm{X}$ dan $\mathrm{Y}$, bernilai positif) dan titik balik minimum berada di daerah negatif (variabel $\mathrm{Y}$ bernilai negatif). Kedua titik tersebut terletak berhimpit dengan garis lurus yang sejajar dengan sumbu X.

Misalnya, tentang masalah riba sebagai batas maksimal positif yang tidak boleh dilanggar dan zakat sebagai batas minimal negatif yang boleh dilampauinya. Maksudnya adalah riba yang berlipat ganda tidak diperbolehkan, sedangkan orang yang mau melakukan zakat di atas ketentuan sebagai batas minimal diperbolehkan. Hal tersebut kemudian menjadi shadaqah yang mempunyai dua batas yaitu batas maksimal pada daerah positif dan batas minimal pada daerah negatif. ${ }^{41}$

Dari beberapa penjelasan tentang teori batas yang ditawarkan oleh Syahrur, maka dapat dikatakan bahwasanya ada dua teori batas yang dipakai oleh Syahrur dalam memahami konsep jilbab dalam al-Qur'an yaitu hadd al-A'la (batas maksimal) dan hadd al-Adna (batas minimal). Adapun penjelasan mengenai hal tersebut secara lebih rinci akan dijelaskan pada pembahasan selanjutnya.

\section{Rekonstruksi Konsep Jilbab Perspektif Syahrur}

Menurut Syahrur, di dalam al-Qur'an setidaknya terdapat dua ayat yang menjelaskan permasalahan tentang jilbab. Pertama, ayat tentang jilbab yang ditujukan secara umum bagi seluruh perempuan beriman, sebagaimana berikut :

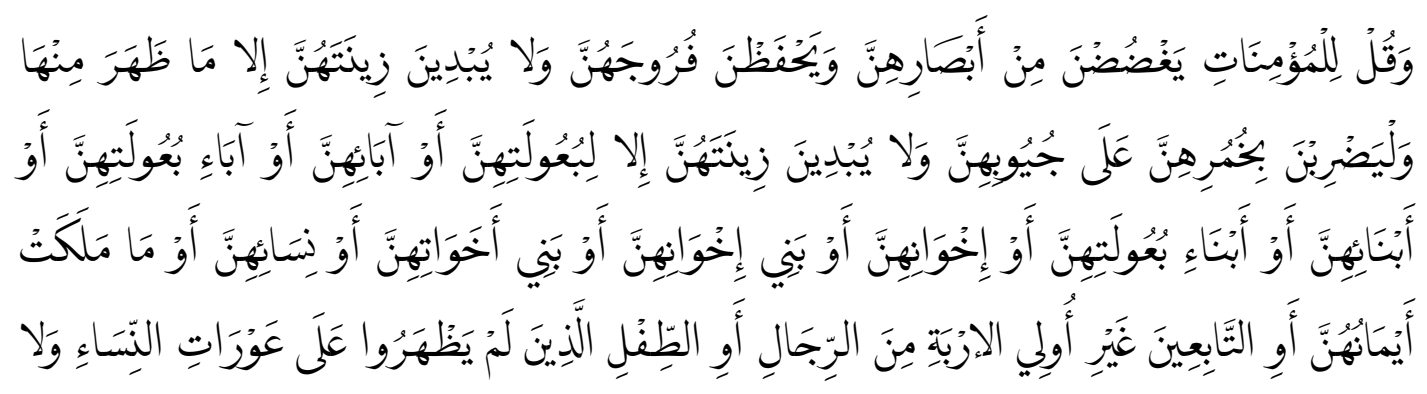

\footnotetext{
${ }^{40}$ Abdul Mustaqim, dkk, Kajian al-Qur'an dan Hadis dalam Dialektika Kontemporer, 110.
}

${ }^{41}$ Abdul Mustaqim, dkk, Kajian al-Qur'an dan Hadis dalam Dialektika Kontemporer, 111. 


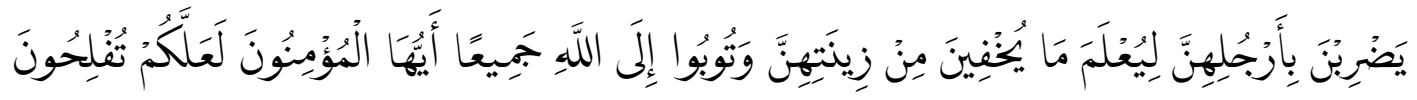

"Katakanlah kepada wanita yang beriman: "Hendaklah mereka menahan pandangannya, dan kemaluannya, dan janganlah mereka Menampakkan perhiasannya, kecuali yang (biasa) nampak dari padanya. dan hendaklah mereka menutupkan kain kudung kedadanya, dan janganlah Menampakkan perhiasannya kecuali kepada suami mereka, atau ayah mereka, atau ayah suami mereka, atau putera-putera mereka, atau putera-putera suami mereka, atau saudara-saudara laki-laki mereka, atau putera-putera saudara lelaki mereka, atau putera-putera saudara perempuan mereka, atau wanitawanita Islam, atau budak- budak yang mereka miliki, atau pelayan-pelayan laki-laki yang tidak mempunyai keinginan (terhadap wanita) atau anak-anak yang belum mengerti tentang aurat wanita. dan janganlah mereka memukulkan kakinya agar diketahui perhiasan yang mereka sembunyikan. dan bertaubatlah kamu sekalian kepada Allah, Hai orang-orang yang beriman supaya kamu beruntung." (Q.S. anNur[24]: 31).

Adapun sebab turunnya ayat tersebut dijelaskan dalam sebuah riwayat yang berasal dari Muqatil ibn Sulaiman, dia berkata: "telah sampai kabar kepada kami bahwa Jabir bin Abdillah berkata bahwa Asma binti Murtad sedang berada di kebun kurma miliknya. Kemudian dia mengundang beberapa teman perempuannya untuk masuk ke dalamnya. Akan tetapi gelang kaki mereka terlihat karena mereka tidak mengenakan kain penutup kaki. Begitu juga dengan gelungan rambut dan bagian dada mereka terlihat. Maka Asma berkata: "alangkah buruknya ini". Kemudian turunlah ayat tentang hal tersebut."42

Dijelaskan juga dalam riwayat lain oleh Ibn jarir dari Hadrami bahwasanya seorang perempuan mengambil mata uang yang terbuat dari emas untuk dibuat menjadi sebuah cincin. Kemudian dia berjalan di depan sekelompok orang dan menghentak-hentakkan kakinya sehingga membunyikan lonceng gelang kakinya. Dari hal tersebut kemudian turunlah ayat tersebut. ${ }^{43}$

Sebelumnya perlu dijelaskan tentang makna perhiasan (az-zinah) pada ayat tersebut. Perhiasan dalam Q.S. an-Nur[24]: 31 terbagi menjadi dua, yaitu: perhiasan yang tampak (azzinah az-zahirab) dan perhiasan yang tersembunyi (az-zinah al-makhfyah). ${ }^{44}$ Selain itu, perhiasan memiliki tiga macam bentuk yaitu: perhiasan berwujud benda (zinah al-ashya) yaitu perhiasan yang berupa penambahan suatu benda ke benda yang lain untuk memperindahnya. Perhiasan tempat atau lokasi (zinah al-mawaqi atau zinah al-makaniyah) yaitu perhiasan yang tampak jelas berupa ruang-ruang publik di daerah perkotaan. Gabungan antara perhiasan yang bersifat lokasi dan kebendaan yaitu sebagaimana dalam Q.S. al-A'raf[7]: $32^{45}$ dan Q.S. Yunus[10]: $24{ }^{46}$

${ }^{42}$ Muhammad Syahrur, Metodologi Fiqih islam Kontemporer, 492.

${ }^{43}$ Muhammad Syahrur, Metodologi Fiqih islam Kontemporer, 493.

${ }^{44}$ Muhammad Syahrur, Metodologi Fiqih islam Kontemporer, 516.

${ }^{45}$ Adapun ayat yang dimaksudkan adalah sebagai berikut :

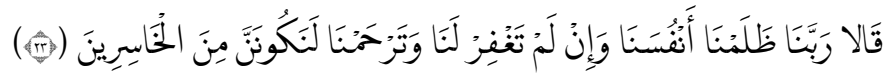

"Keduanya berkata: "Ya Tuhan Kami, Kami telah Menganiaya diri Kami sendiri, dan jilka Engkau tidak. mengampuni Kami dan memberi rabmat kepada Kami, niscaya pastilab Kami Termasuk orang-orang yang merugi"

${ }^{46}$ Adapun ayat yang dimaksudkan adalah sebagai berikut : 
Selanjutnya, tubuh perempuan dapat dibagi menjadi dua, yaitu : pertama, bagian tubuh yang terbuka secara alami (qism az-zahir bi al-khalq). Perhiasan yang tampak adalah apa yang secara alami tampak pada tubuh perempuan, yaitu apa yang diperlihatkan oleh Allah dalam penciptaan tubuh perempuan. Seperti kepala, perut, punggung, dua kaki, dan dua tangan. ${ }^{47}$

Kedua, bagian tubuh yang tidak tampak secara alami (qism ghair az-zabir bi al-khalq) yaitu bagian yang disembunyikan oleh Allah dalam bentuk dan susunan perempuan. Bagian tersebut dinamakan al-juyzub atau bagian-bagian yang berlubang. Kata al-juyüb berasal dari kata jā-yā-bà seperti dalam perkataan jabtū al-qämisa, artinya aku melubangi bagian saku baju atau aku membuat saku pada baju. Kata al-juynūb adalah bagian terbuka yang memiliki dua tingkatan, bukan satu tingkatan karena pada dasarnya kata jā-ya-bo berasal dari kata jā-w $\bar{a}-b \bar{a}$ yang memiliki arti dasar "lubang yang terletak pada sesuatu" dan juga berarti pengembalian perkataan "soal dan jawab". Istilah al-juyüb pada tubuh perempuan memiliki dua tingkatan sekaligus sebuah lubang yang secara rinci berupa: bagian antara dua payudara, bagian bawah payudara, bagian bawah ketiak, kemaluan dan pantat. ${ }^{48}$ Oleh karenanya, Allah memerintahkan perempuan muslimah untuk menutupi semua bagian yang dinamakan dengan al-juyūb yaitu perhiasan yang tersembunyi secara fisik serta melarang perempuan tersebut untuk memperlihatkannya.

Kedua, ayat tentang jilbab yang ditunjukkan kepada istri rasul dan istri orang-orang beriman, sebagaimana berikut :

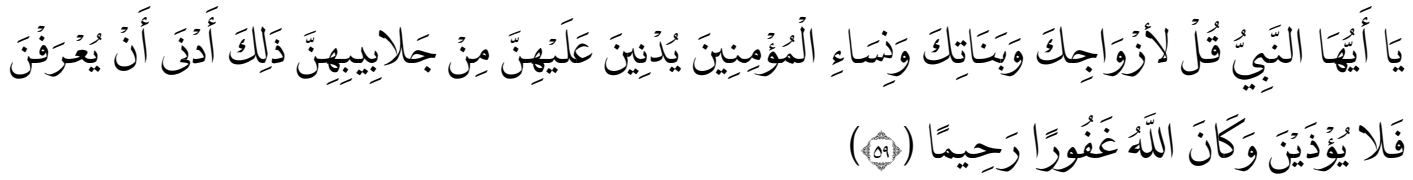

"Hai Nabi, Katakanlah kepada isteri-isterimu, anak-anak perempuanmu dan isteri-isteri orang mukmin: "Hendaklah mereka mengulurkan jilbabnya ke selurub tubuh mereka". yang demikian itu supaya mereka lebih mudah untuk dikenal, karena itu mereka tidak di ganggu. dan Allah adalab Maha Pengampun lagi Maha Penyayang.”(Q.S. Al-Ahzab[33]: 59).

Adapun sebab turunnya ayat tersebut dijelaskan dalam sebuah riwayat dari Aisyah, dia berkata : "suatu ketika sesudah diwajibkan hijab atas istri-istri nabi, Saudah pergi keluar untuk memenuhi kebutuhannya." Ketika di perjalanan, Saudah bertemu dengan Umar lalu Umar berkata : "wahai Saudah apa yang kau sembunyikan dari kami? Maka telitilah bagaimana kau berpakaian untuk pergi keluar". Kemudian Saudah pulang, pada saat itu, Rasulullah sedang makan malam dan di tangannya terdapat segenggam irq (daging yang masih melekat pada sepotong tulang). Saudah pun berkata kepada Rasulullah : "wahai Rasul, ketika aku pergi keluar untuk memenuhi sebagian kebutuhanku Umar berkata kepadaku

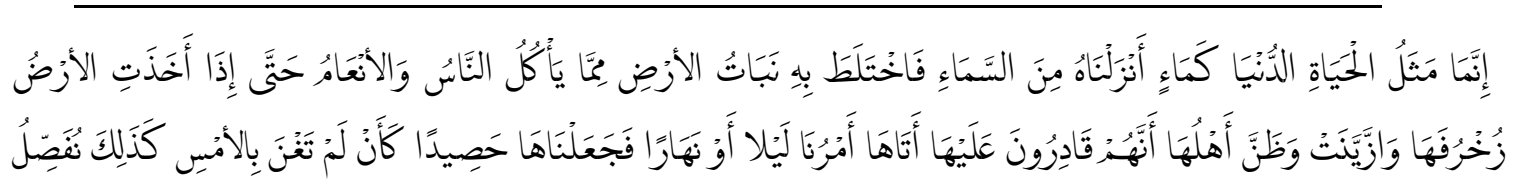

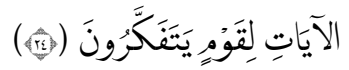

"Sesungguhnya perumpamaan kehidupan duniawi itu, adalah seperti air (hujan) yang Kami turunkan dan langit, lalu tumbuhlah dengan suburnya karena air itu tanam-tanaman bumi, di antaranya ada yang dimakan manusia dan binatang ternak. hingga apabila bumi itu telah sempurna keindahannya, dan memakai (pula) perhiasannya dan pemilik-permliknya mengira bahwa mereka pasti menguasasinya, tiba-tiba datanglah kepadanya azab Kami di waktu malam atau siang, lalu Kami jadikan (tanam-tanamannya) laksana tanamtanaman yang sudah disabit, seakan-akan belum pernah tumbuh kemarin. Demikianlah Kami menjelaskan tanda-tanda kekuasaan (Kami) kepada orang-orang berfikir."

${ }^{47}$ Muhammad Syahrur, Metodologi Fiqih islam Kontemporer, 517.

${ }^{48}$ Muhammad Syahrur, Metodologi Fiqih islam Kontemporer, 517-518. 
seperti ini dan seperti ini", kemudian Allah menurunkan wahyu kepada Rasulullah, maka beliau mengangkat tangannya sementara dalam genggamannya masih terdapat irq. Rasulullah berkata : "Sesungguhnya Allah mengizinkan kalian (para perempuan) untuk keluar memenuhi kebutuhan kalian" (al-Bukhari: 4421). ${ }^{49}$

Dijelaskan juga dalam riwayat lain oleh Ibnu Sa'd dalam at-Tabaqat dari Abu Malik, dia berkata : "suatu ketika istri-istri Nabi pergi keluar pada malam hari untuk memenuhi kebutuhannya". Ketika di perjalanan, segolongan orang munafik menyaksikannya dan berusaha mengganggu mereka. Kemudian mereka melaporkan hal tersebut kepada Rasulullah. Lalu Rasulullah memberikan peringatan kepada golongan orang munafik tersebut, akan tetapi mereka menjawab : "sesungguhnya kami hanya melakukan hal itu kepada hamba-hamba sahaya perempuan," maka turunlah ayat tersebut. ${ }^{50}$

Dari penjelasan kedua riwayat di atas terlihat bahwasanya ayat tersebut berbicara kepada Rasulullah dalam wilayah nubuwwah, karena ayat tersebut diturunkan berdasarkan dengan kondisi-kondisi objektif yang berlaku pada masa Nabi. Di dalamnya ditetapkan dua sebab pemberlakuan ajaran hukum, yaitu : pengenalan (al-ma'rifah) dan adanya gangguan (al$a d h a) .{ }^{51}$ Menurut Syahrur, perempuan muslimah diwajibkan untuk menutup bagian-bagian tertentu pada tubuhnya apabila yang ditampakkan menyebabkan adanya gangguan (al-adha). Akan tetapi, ayat tersebut berfungsi sebagai ayat ta'limiyah (pengajaran/informasi), bukan sebagai ayat tashriiyah (penetapan hukum). ${ }^{2}$ Sehingga jika dikaitkan dengan asbab an-nuzul ayat tersebut maka menurut Syahrur jilbab bukanlah kewajiban melainkan hanya tradisi orang Arab. Karena pada saat itu perbudakan masih berlaku, maka kemudian diberlakukanlah jilbab untuk membedakan antara budak perempuan dengan perempuan merdeka.

Menurut Syahrur, gangguan (al-adha) terdiri dari dua macam, yaitu bersifat alami dan sosial. Gangguan alami terkait dengan lingkungan geografis, seperti suhu udara dan cuaca. Perempuan seharusnya berpakaian sesuai dengan kondisi suhu dan cuaca yang ada ditempat tinggalnya sehingga tidak menimbulkan gangguan alami pada dirinya. Kata fa pada ayat 'an yu'rafna fa lâ yu'džayna menunjukkan adanya suatu sebab (fa as-sababiyab) dan akibat (ta'qib) anatara pengetahuan dan gangguan. Hal Inilah yang kemudian disebut dengan gangguan sosial (al-adha al-ijtima'i). ${ }^{53}$

Oleh karenanya, jika diterapkan pada masa sekarang maka pemberlakuan ayat tersebut dapat berupa prosedur bepergian bagi perempuan yang disesuaikan dengan kondisi pada tempat masing-masing. Sehingga akan terpenuhi tujuan utamanya yang tidak lain adalah untuk menjaga keselamatan dan juga terhindar dari gangguan bagi perempuan yang hendak bepergian ke luar.

Selanjutnya, kata jilbab menurut Syahrur berasal dari kata ja-la-ba dalam bahasa Arab yang memiliki dua arti dasar, yaitu : pertama, mendatangkan sesuatu dari satu tempat ke tempat lain. Kedua, sesuatu yang menutupi sesuatu yang lain. Kata al-jalabah berarti sobekan kain yang digunakan untuk menutupi luka sebelum bertambah parah dan bernanah. Dari pengertian tersebut muncullah kata al-jilbab untuk perlindungan yaitu pakaian luar yang berupa celana panjang, baju, seragam resmi, mantel dan lain-lain. Seluruh bentuk pakaian tersebut termasuk dalam pengertian al-jalabib. ${ }^{54}$

Allah berfirman dengan redaksi "yudnina 'alaybinna min jalabibibinna". Pada ayat tersebut Allah menggunakan huruf jarr yaitu "min" yang berfungsi untuk menunjukkan sebagian dari keseluruhan (at-ta'bid) dan menggunakan kata yudnina yang berfungsi untuk mendekatkan

\footnotetext{
${ }^{49}$ Muhammad Syahrur, Metodologi Fiqih islam Kontemporer, 491.

${ }^{50}$ Muhammad Syahrur, Metodologi Fiqih islam Kontemporer, 491.

${ }^{51}$ Muhammad Syahrur, Metodologi Fiqih islam Kontemporer, 533.

${ }^{52}$ Muhammad Syahrur, Metodologi Fiqih islam Kontemporer, 492.

${ }^{53}$ Muhammad Syahrur, Metodologi Fiqih islam Kontemporer, 533.

${ }^{54}$ Muhammad Syahrur, Metodologi Fiqih islam Kontemporer, 532.
} 
(taqrib). Kata tersebut berasal dari kata danawa-yadnu. Kata al-jalb dan al-idna memiliki makna yang serasi. Aktivitas mendekat disebut dengan kata al-jalb. Baju yang tidak bersentuhan dengan tubuh disebut addunumw. ${ }^{55}$

Dari seluruh penjelasan di atas, maka penulis dapat menyimpulkan bahwasanya Q.S. Al-Ahzab[33]: 59, menurut Syahrur adalah ayat yang berfungsi sebagai pengajaran, bukan sebagai penetapan hukum. Sehingga menggunakan jilbab menurutnya adalah tidak wajib, karena jilbab pada konteks ayat tersebut lebih termasuk pada tradisi orang Arab pada saat itu yang mana sistem perbudakan masih berlaku. Point intinya adalah jilbab digunakan sebagai pembeda antara perempuan budak dan perempuan merdeka. Selain itu, jilbab juga digunakan sebagai pelindung agar terhindar dari gangguan luar yang menimpanya. Jadi pakaian apapun boleh digunakan asalkan dua hal tersebut sudah terpenuhi.

Dalam kaitannya dengan teori batas yang dirumuskannya, Syahrur menyatakan bahwasanya batas minimal (hadd al-adna) pakaian perempuan yang berlaku secara umum adalah menutup daerah inti bagian atas (al-juyzūb al-ulwiyyah), yaitu daerah payudara dan bawah ketiak, dan juga menutup daerah inti daerah bawah (al-juyzīb as-sufliyyah). Adapun dalam kaitannya dengan ketentuan aurat sebagaimana dalam hadis nabi, yaitu seluruh badan perempuan, kecuali wajah dan telapak tangan, maka bisa dikatakan bahwa hadd al-andā adalah bagian yang termasuk dalam kategori al-juyüb, baik al-juyub al-ulwiyyah atau al-juyüb as-sufliyyah.

Sedangkan batas maksimal (hadd al-A'la) yang berlaku secara umum adalah sebagaimana dalam hadis Nabi: yaitu seluruh tubuh perempuan kecuali wajah dan kedua telapak tangan karena keduanya termasuk dalam "maa zabara minha". Pada hadis tersebut, Nabi telah membolehkan perempuan untuk menutup seluruh tubuhnya sebagai batas maksimal, akan tetapi Nabi tidak membolehkan perempuan dalam kondisi bagaimana pun untuk menutup wajah dan telapak tangannya, karena wajah manusia adalah ciri khasnya. Jika seorang perempuan pergi keluar dengan hanya berpakaian yang menutup daerah intim bagian bawah saja (al-juyūb as-sufliyyah), maka ia telah keluar dari batasan Allah dan jika ia keluar tanpa memperlihatkan sedikitpun dari anggota tubuhnya, bahkan hingga wajah dan kedua telapak tangannya, maka ia telah keluar dari batasan Rasulullah. ${ }^{56}$

Jadi, konsekuensinya bagi perempuan yang menampakkan bagian al-juyzub berarti dia telah melanggar budüd Allah. Begitu juga perempuan yang menutup seluruh tubuhnya tanpa terkecuali, maka dia juga melanggar budūd Allah.

\section{Catatan Kritis}

Terlepas dari kontroversi terhadap pemikirannya, Syahrur adalah salah satu cendikiawan Muslim yang mempunyai pemikiran baru dalam kajian kontemporer. Syahrur ingin membuktikan bahwasanya al-Qur'an dapat berlaku di setiap zaman, tidak terkecuali zaman modern saat ini. Sehingga maksud dari al-Qur'an dapat tetap sampai kepada para pembacanya. Menurut hemat penulis, pemahaman Syahrur terhadap konsep jilbab dalam alQur'an yang kemudian berkaitan dengan menutup aurat bagi perempuan Muslimah boleh jadi dibenarkan. Sebelumnya Syahrur menjelaskan bahwasanya makna aljuyüb adalah bagianbagian yang berlubang. Akan tetapi, jika dicermati lebih lanjut misalnya pada batas minimal (hadd al-Adna) yaitu menutup daerah bagian atas (al-juyub al-ulwiyah), yaitu daerah payudara, bawah ketiak, dan menutup daerah intim bagian bawah (al-juyub as-sufliyyah). Maka disitu terlihat kurang konsistennya Syahrur terhadap pengertian al-juyūb. Karena pada penjabarannya tentang al-juyüh, Syahrur tidak menyebutkan hidung, telinga dan mulut. Padahal kesemuanya adalah bagian-bagian yang berlubang.

Selanjutnya, Syahrur mengatakan bahwasanya jilbab bukanlah suatu kewajiban melainkan hanya sebuah tradisi orang Arab pada saat dimana sistem budak masih berlaku. Pada waktu itu, kebiasaan orang Arab pada malam hari adalah mengganggu perempuan

\footnotetext{
${ }^{55}$ Muhammad Syahrur, Metodologi Fiqih islam Kontemporer, 532-533.
}

${ }^{56}$ Muhammad Syahrur, Metodologi Fiqih islam Kontemporer, 534. 
budak yang keluar malam untuk memenuhi hajatnya. Oleh karenanya turunlah al-Ahzab [33]: 59 yang memerintahkan perempuan merdeka untuk menggunakan jilbab sebagai pembeda dengan perempuan budak serta untuk melindungi diri dari gangguan orang lain. Akan tetapi, menurut Syahrur ayat tersebut lebih berfungsi sebagai pengajaran, bukan penetapan hukum.

Pendapat tersebut menurut penulis dapat dijadikan sebagai alternatif diantara pendapat-pendapat lainnya tentang jilbab. Karena permasalahan tentang jilbab selalu banyak menimbulkan pro dan kontra diantara para ulama kontemporer maupun ulama-ulama mazhab. Pendapat Syahrur yang menganggap bahwasanya jilbab tidak wajib, secara tidak langsung bisa bermakna wajib. Karena pada konteks saat ini sistem budak sudah tidak berlaku maka tujuan berjilbab lebih sebagai penghindar dari gangguan bukan sebagai pembeda. Asalkan tujuannya sudah terpenuhi yaitu terhindar dari gangguan maka seorang perempuan boleh menggunakan pakaian apapun. Akan tetapi menurut penulis, dalam konteks saat ini terutama di Indonesia, pakaian terbaik untuk menghindari gangguan adalah dengan menggunakan jilbab, meskipun jilbab sudah sangat bervariasi macam dan bentuknya.

\section{Simpulan}

Syahrur adalah cendikiawan Muslim kontemporer yang menawarkan berbagai teori inovatif dalam kajian hukum Islam. Salah satu teroinya adalah tentang teori batas (hudud). Menurutnya, ada enam bentuk teori batas yaitu : Halah al-had al-a'la, Halah al-badd al-adna, Halah al-haddayn al-a'la wa al-adna ma'an, Halah al-mustaqim, Halah al-hadd al-a'la duna al-mamas bi al-hadd al-adna abadan, dan Halah al-hadd al-a'la mujaban wa al-hadd al-adna saliban. Dalam kaitannya dengan jilbab, Syahrur menggunakan dua bentuk teori batas yaitu hadd al-A'la (batas maksimal) dan hadd al-Adna (batas minimal).

Adapun pemahaman Syahrur terhadap konsep jilbab pada Q.S. an-Nur [24]: 31 dan alAhzab [33]: 59 yaitu pada batas minimal (hadd al-Adna) yang berlaku secara umum adalah menutup daerah bagian atas (al-juyub al-ulwiyah), yaitu daerah payudara, bawah ketiak, dan menutup daerah intim bagian bawah (al-juyub as-sufliyyah). Sedangkan batas maksimal (hadd al$A^{\prime}$ 'a) yang berlaku secara umum adalah bagian yang termasuk dalam kategori al-juyūh, baik aljuyub al-ulwiyyah atau al-juyzub as-sufliyyah yaitu seluruh tubuh perempuan kecuali wajah dan kedua telapak tangan.

\section{Daftar Pustaka}

Abied, M. Aunul, (2001). Islam Garda Depan; Mozaik Pemikiran Islam Timur Tengah, Bandung: Mizan.

Guindi, Fadwa El, (2003). Jilbab: Antara Kesalehan, Kesopanan dan Perlawanan, terj. Mujiburohman, Jakarta: Serambi.

Ismail, Ahmad Syarqawi, (2003). Rekonstruksi Konsep W abyu Mubammad Syahrur, Yogyakarta: eLSAQ Press.

Kurdi, dkk, (2010). Hermenentika al-Qur'an dan Hadis, Yogyakarta: eLSAQ Press.

Mernissi, Fatima, (1994). Wanita di dalam Islam, terj. Yaziar Radianti, Bandung: Pusta.ka

Mubarok, Ahmad Zaki, (2007). Pendekatan Strukturalisme Linguistik dalam Tafsir al-Qur'an Kontemporer "ala" M. Syahrur, Yogyakarta: eLSAQ Press.

Munawwir, Ahmad Warson, (1997). al-MunawnIr Kamus Arab Indonesia, Surabaya: Pustaka Progressif.

Mustaqim, Abdul, (2008). Epstemologi Tafsir Kontemporer, Yogyakarta: LkiS. , dkk, Kajian al-Qur'an dan Hadis dalam Dialektika Kontemporer, Yogyakarta: Idea Press, 2014.

Salsabila, Qabila, dkk, (2017). Penafsiran Ayat-Ayat Tentang Aurat Perempuan Menurut Mubammad Syahrur, Al-Bayan: Jurnal Studi al-Qur ${ }^{\text {ee }}$ an dan Tafsir 2, 1 Juni. 
Shihab, Quraish, (2000). Wawasan al-Qur'an, Tafsir Maudhu'i atas Pelbagai Persoalan Umat, Bandung: Mizan.

Syahrur, Muhammad, (2008). Prinsip dan dasar Hermeneutika al-Qur'an Kontemporer, terj. Sahiron Syamsuddin, Yogyakarta: eLSAQ Prees.

, (2015). Metodologi Fiqih islam Kontemporer, terj. Sahiron Syamsuddin, Yogyakarta: Kalimera.

, (2015). Epistimologi Qur'ani: Tafsir Kontemporer Ayat-ayat al-Qur'an Berbasis MaterialismeDialektika-Historis, terj. M. Firdaus, Bandung: Penerbit Marja.

$\longrightarrow$, (2002). Islam dan Iman: Aturan-aturan Pokok, terj. M. Zaid Su'di, Yogyakarta: Penerbit Jendela, 2002.

Syamsuddin, Sahiron, (2003). dkk. Hermeneutika al-Qur'an; Mad乏̧bab Yogya, Yogyakarta: Penerbit Islamika.

Tim Penulis Ensiklopedi Islam, (2003). Ensiklopedi Islam, Jilid I, Jakarta: PT. Ichtiar Baru Van Hoeve.

W.J.S. Poerwadarminta, (2007). Kamus Umum Bahasa Indonesia Edisi Ketiga, Jakarta: Balai Pustaka. 